\title{
Accounting Education for Professional Accountants: Evidence from Italy
}

\author{
Giovanna Lucianelli ${ }^{1} \&$ Francesca Citro $^{2}$ \\ ${ }^{1}$ Department of Management and Law, University of Rome "Tor Vergata", Rome, Italy \\ ${ }^{2}$ Department of Management and Innovation Systems, University of Salerno, Salerno, Italy \\ Correspondence: Francesca Citro, Department of Management and Innovation Systems, University of Salerno, \\ Via Giovanni Paolo II, 132, 84084, Fisciano (SA), Italy. E-mail: fcitro@unisa.it
}

Received: April 24, 2018

doi:10.5539/ijbm.v13n8p1
Accepted: May 17, 2018

Online Published: June 30, 2018

\begin{abstract}
In the last years, the worldwide changes in global, political and financial contexts have gradually modified the approaches to the accounting of national governments and international institutions. In this varying scenario, the International Accounting Standard Board (IASB) and consequently national governments have introduced new accounting standards along with related regulatory changes. These issues are of ever-growing importance when considering that the International Accounting Education Standards Board (IAESB) has recently developed "The basis for conclusions document for 2017-2021 IAESB Strategy and 2017-2018 Work Plan" (IAESB, 2017) with the aim of informing the Board's deliberations on its future strategy and priorities about the future expectations of professional competence. The aim of this paper is to report the findings of an empirical study on this topic and address the following research question: what are professional accountants' views on quality in accounting education? This primary research question is expanded to consider professional accountants' beliefs on the present (what is necessary for their workplace) and future (what will be necessary for their workplace) with respect to quality in accounting education. The survey highlights how professional accountants have more expectations than in the past about their skills. The majority of professional accountants have been transforming themselves into business consultants since they are now required to offer more services than accounting and taxation consultancy. Consequently, there is a growing demand for cooperation with the university world in order to broaden the programs of accounting education with new technical competencies for undergraduate and postgraduate degrees.
\end{abstract}

Keywords: accounting education, professional accountants, international accounting education standards board

\section{Introduction}

The worldwide changes in global, political and financial contexts over the last three decades have highlighted some critical aspects in accounting education in order to train graduates with adequate professional competencies. As important institutions have underlined (American Accounting Association, 1986; American Institute of Certified Public Accountants, 1998; Institute of Management Accountants, 1994, 1996, 1999; IAESB, 2014, 2015; IFAC, 2015a, 2015b) the academic programs generally remain usually focused on theoretical issues and do not care about the difficulty of accountants and employers of dealing with a growing complexity in their work. More skills, and personal attributes are now required to become successful as professional accountants (Andersen et al., 1989; Brown \& McCartney, 1995).

Some authors have also underlined the perceived gap by graduating accounting students in their performance: at the end of their courses they do not feel as if they have enough competencies to find a job or a place in professional studios without developing personal competencies and practice (Bui \& Porter, 2010; Stephenson, 2017).

It is worth highlighting how there are different studies on the factors that increase the gap in expectations; some of them are focused on subjects that perceive the gap: academics and employers (Armitage, 1991; Novin, Fetyko, \& Tucker, 1997; Theuri \& Gunn, 1998; Francis \& Minchington, 1999) and students (Shivaswamy \& Hanks, 1985a, 1985b; Kochanek \& Norgaard, 1985; Felton, Buhr \& Northey, 1994; Marriott \& Marriott, 2003; Sikka et al., 2007); while other studies highlight the institutional constraints (Street, Baril \& Benke, 1993; Manakyan \& 
Tanner, 1994; Lindsay \& Campbell, 1995; Murdoch \& Guy, 2002; Duncan \& Schmutte, 2006; Hill \& Milner, 2007) as well as the ineffectiveness of university teaching (Wolk, Schmidt \& Sweeney, 1997; Swain \& Stout, 2000).

Starting from the different point of views this paper explores the inadequacy of accounting education to form graduates with the necessary skills as requested by professional accounting bodies, accountants and employers in accountancy.

The main research question is about professional accountants' views on the quality in accounting education. This subject is expanded to consider professional accountants' beliefs about the present (what is necessary for their workplace) and future (what will be necessary for their workplace), assuming that quality expectations in technical competence are expressed in the IES 2.

This study initially explores first the Italian university path to obtain accounting skills followed by the professional bodies expectations about accounting education.

The survey highlights how professional accountants have more expectations than in the past about their skills. The global financial crisis, along with other factors involve processes of adaptation to the new scenario. The majority of professional accountants have been transforming themselves into business consultants since they are now required to offer more services than accounting and taxation consultancy. Consequently, there is a growing demand of cooperation with the university world in order to broaden the programs of accounting education with new technical competencies for undergraduate and postgraduate degrees. Furthermore, in the last two decades, universities worldwide are facing a wide reform of the whole system, based on the aspiration of policymakers to introduce budgetary restriction and a more 'rational' management in order to improve efficiency, effectiveness, and accountability. Consequently, it is essential that members of the accounting profession, university administrators, and policymakers share the idea about what a university accounting education can deliver (Collini, 2012).

The findings of this study provide valuable input to a theme that has not been widely discussed in Italy. In the absence of any previous empirical research that has sought to identify these perceptions, the findings fill the gap in current literature by clearly identifying the view of a key stakeholder group in Italy: professional accountants.

The paper is organised as follows. The next section summarises the Italian context, defining the Italian accounting profession as well as the accounting education paths for professionals. The third section presents a detailed literature review on the mismatch between university programs of accounting education and professional skills expectations, while the fourth illustrates the contents of the IES 2 (Initial Professional Development - Technical Competence) issued by the IAES.

The fifth section discusses both the research design and methodology as well as the results, while the last section presents several conclusions and indications for future developments.

\subsection{Accounting Profession and Accounting Education for Professionals in Italy}

In Italy, the admission to the accounting profession has been possible for many years to anyone who had completed high school. In 1953, some accountants were graduates and they created their own association, which separated them from the non-graduate group. In 1997, the profession became wholly graduate-only with a requirement that to become a professional accountant (ragioniere), entrants were required to hold a 3-year Bachelor's degree. To become a "dottore commercialista" (the equivalent of a "chartered accountant") before the reform of the Italian University System (Ministerial Decree no. 509/99), a 4-year degree was first required, since the adoption of the Ministerial Decree no. 509/99, this was changed to a requirement of a 3-year Bachelor's degree plus a 2-year's Master's degree (Costa, Torrecchia \& Sangster, 2013).

In 2005, it was agreed to merge the two professional groups with effect from the start of 2008 (Note 1). From this point on, all new entrants to the new combined body, the National Council of Certified Accountants and Accounting Experts (Consiglio Nazionale dei Dottori Commercialisti e degli Esperti Contabili, hereafter CNDCEC) were required to be qualified and have completed a period of professional training as well as passed the necessary state examinations. Currently, the profession includes those with Master's degrees (5 years of university education), a "Chartered accountant", as well as those with Bachelor's degrees ( 3 years of university education), an "Accounting expert" (Costa, Torrecchia, \& Sangster, 2013). It should be noted that the chartered accountant has a wider theoretical and practical knowledge of accounting in the broad sense, and thus can work more extensively and perform more functions than an accounting expert.

The education programs for Bachelor's and Master's degrees are proposed by universities to the Ministry of 
Education and Research (MIUR), in order to be examined and approved by the National University Council (CUN). The courses must satisfy the requirements of the National Law (Ministerial Decree 22 October 2004, n. 270) for the educational offer ("offerta formativa").

In addition, on October 13, 2010 the Ministry of Education, University and Research and CNDCEC signed a Framework Agreement to intensify the collaboration between university and profession. This Agreement has represented an important step of cooperation since it allows for a substantial delineation of the whole training path followed by the future accountants, coordinating both the content of the degree programs as well as and the professional courses for the preparation of the state examinations for becoming Certified Accountants and Accounting Experts and the characteristics of the professional practice.

Finally, the territorial Orders of Certified Accountants and Accounting Experts (Ordini dei Dottori Commercialisti e degli Esperti Contabili territoriali, hereafter ODCEC) manage the education programs for "chartered accountants" (FNA, 2014) (Note 2).

In other words, there are two different paths of accounting education: one is offered by universities with Bachelor's and Master's degrees in Economics, while the other is offered by the territorial Orders of Certified Accountants, but only for Continuing Professional Training (hereafter CPT). The current regulations on CPT in line with the international standards identified by IFAC provides that the chartered accountants and accounting experts must acquire at least 90 credits over three years, with a minimum of 20 verifiable credits for each year. At least three credits must mature annually in the following subjects: organization, ethics, tariffs, organization of the professional office. The territorial ODCEC encourage the organization of free education by providing a wide range of training (with its own resources or obtaining specific grants from financing bodies) through the promotion and organization of activities, thus providing more opportunities and tools to upgrade; the responsibility for the monitoring and content of the courses is up to the territorial ODCEC.

\section{Review of the Relevant Literature}

There are two main paths in order to further deepen the relevant literature on this theme. The first deals with studies in the field of accounting education with a focus on how academic accounting programs for professionals ought to be. The second path is more related to accountants' skill expectations and deals with the existing gap between what accountants really do and what accounting educators teach. This paragraph is consequently divided into two parts as follows.

\subsection{Accounting Education for Professionals}

The birth of modern accounting and the interrelationship between the profession and academia (McGee, 2005; McGee \& Preobragenskaya, 2005) are highlighted through numerous studies as well as the ongoing debate.

The American Accounting Association's Bedford Committee Report in 1986, as well as the Report of the Review of the Accounting Discipline in Higher Education (The Mathews Report) complained about the failure of accounting programs to meet the requirements of the profession (Mathews, Jackson \& Brown, 1990).

The emergent competitive accounting market required accountants to have a broadly based education and knowledge of both accounting information systems as well as the role of the accountants within an entity.

The Bedford Committee Report identified that accounting services had become both broader and more specialised; at the same time, the management advisory services require the development of specialised expertise. As a consequence, professional accountants had to increase their range of accounting specializations (with distinct practical learning needs). Moreover, the Perspectives on Education White Paper (Andersen et al., 1989) identified several skills and knowledge required by accountants in practice such as communication, intellectual and interpersonal skills, along with accounting, auditing, and organizational competencies.

Along with this path, a study by the American Institute of Certified Public Accountants (AICPA, 1998) has pointed out the relevance of the accounting graduates and the professional accountants to detain technical accounting competencies, organisational and business competencies in order to stay competitive in the changing business context. Similarly, the Education Committee of the International Federation of Accountants (IFAC, 2002) has identified strategic thinking and management, leadership and interpersonal skills as the main abilities to promote in order to face the complexity of accounting issues and work in an environment that is continuously changing.

Accordingly, several scholars have emphasized how academics have a key role in developing students' intellectual capability and using critical thinking (Jackson, 2009; Carmona, 2013; Jackson, 2016). 


\subsection{Professional Skill Expectations}

There is a relevant number of studies that underlined that the main problems of education were the growing gap exists between what accountants do and what accounting educators teach (Albrecht \& Sack, 2000; Birrell, 2006; Bui \& Porter, 2010; Freeman, Simpson \& Taylor, 2008; Hancock et al., 2009; Jackling \& De Lange, 2009; Jackson et al., 2006, Freeman \& Hancock, 2011; De Lange, Jackling \& Suwardy, 2015; Jackson, 2016; Stephenson, 2017), rather than focusing on why accounting education should change.

A consistent strand of literature has identified several differences in the expectations of practitioners on the subject matter taught in the academic courses in accounting (Armitage, 1991; Novin, Fetyko, \&Tucker, 1997; Theuri \& Gunn, 1998; Francis \& Minchington, 1999; Parry \& Jackling 2015; Jackson, 2016; Stephenson, 2017). For example, Albrecht and Sack (2000), highlighted some difficulties facing accounting education such as the decrease of the enrolments in accounting programs and the obsolete accounting education process.

Some authors (Frecka and Nichols, 2004; Parker, 2007; Wilson, 2011; Byrne et al., 2012;) pointed out that academic accounting courses should focus on restricting topics with an over-emphasis on technical content; on the other hand, practitioners preferred a wider coverage of themes (Cranmer, 2006; Bui \& Porter, 2010).

For other authors (Kavanagh \& Drennan, 2008; Bayerlein, 2015; Bayerlein \& Timpson, 2017; Osmani et al., 2017), the gap between education programs and practices could be due to the failure of educators to deal with face with the complex changes that are in the nature of the accounting profession.

Another strand of literature underlined that the conflict between teaching and research contributes to the failure of accounting education to provide accounting graduates with the competencies expected of them by the profession (Street, Baril \& Benke, 1993; Manakyan \& Tanner, 1994; Lindsay \& Campbell, 1995; Murdoch \& Guy, 2002; Duncan \& Schmutte, 2006; Hill \& Milner, 2007). Several scholars (Kerr, 1975; Schultz, Meade \& Khurana, 1989; Tang \& Chamberlain, 1997; Porter \& Carr, 1999), pointed out that the evaluation of academic performance is based on the quality of research and publications; thus, this reward system provides little incentive for academics to develop new teaching programs (Marsh \& Hattie, 2002; Hardré \& Collmann, 2012). As a consequence, academics concentrate on research rather than teaching activities (Moya, Prior \& Rodríguez-Pérez, 2015) and continue to adopt traditional teaching styles rather than introduce new ones (Wolk, Schmidt \& Sweeney, 1997).

Some authors have also underlined the perceived gap by graduating accounting students in their performance: at the end of their courses, they do not feel as if they have enough competencies to find a job or a place in professional studios without developing personal competencies and practice (Bui \& Porter, 2010; Stephenson, 2017).

Other scholars underlined that the ineffectiveness of university teaching depends on the lack of sharing of an appropriate accounting program between academics, individual students and employers (Swain \& Stout, 2000; Stice \& Stocks, 2000; Cranmer, 2006; Kavanagh \& Drennan, 2008); other scholars (Willcoxson, Wynder \& Laing, 2010), highlighted how academics think that the accounting program is too overcrowded to introduce new tasks.

In other terms, there are significant barriers to the adoption of new curricula and teaching and learning methods to the requirements of professional accountants (or employers) (Gallhofer, Haslam \& Kamla, 2009; De la Harpe \& David, 2011)

There are a lot of examples (Hancock et al., 2009) of best practices and guidelines on how to implement improved practice but few examples of an accounting program that reflects 'actual' practice (Yap, Ryan \& Yong, 2014; Lubbe, 2015)

Although the professional associations accredit these accounting programs, professional accreditation is not a guarantee of professional readiness (Willcoxson, Wynder \& Laing, 2010, Yap, Ryan \& Yong, 2014).

In Italy, the presence of more than $98 \%$ Smes requires that professional accountants are able to provide more consultancy services to local clients. It is worth noting that about $84 \%$ of Italian enterprises are Micro enterprises (that employ up to nine people) and more than $14 \%$ are small enterprises (that employ between 10 and 49 people) (European Commission, 2015). Furthermore, as in other countries, the impact of the increasingly prominent position of the client has changed the role of the 'traditional accountant' to one of 'advisor' (Lander, Koene \& Linssen, 2013).

In other words, professional accountants should now have new skills expectations from the university education system than in the past and the next step of this paper is to compare them with the technical competencies that 
aspiring professional accountants are required to demonstrate by the end of their initial professional development according to the International Education Standards (IESs).

\subsection{Technical Competencies for Professional Accountants in the International Education Standards (IESS)}

IAESB is one of the several independent standard-setting boards operating under the International Federation of Accountants (IFAC) umbrella. The main IAESB' activities concern the development and enhancement of accountants' education, including both pre-qualification education and training of prospective accountants as well as continuing education training for members of the professional accountants.

The Framework for International Education Standards for Professional Accountants and Aspiring Professional Accountants (the "Framework"), revised in 2015, sets out the concepts that underlie its International Education Standards (IESs).

In the framework, "education is a structured and systematic process aimed at developing knowledge, skills and other capabilities" (values, ethics and attitudes) (IAESB, 2014). This process is typically but not exclusively conducted in the academic environment; in fact, it becomes relevant to a broad range of stakeholders, including employers of professional accountants, chartered accountants and potential chartered accountants

In its draft 2014-2016 strategy and work plan, the IAESB pointed out that its activities will include:

- The exploration of the environmental context in order to detect critical issues about the development and the assessment of professional accounting education;

- The development of a guidance on "how general education is used to develop the professional accountant" and on "entry requirements into professional accounting education programs" (IAESB, 2014, pp. 4 and 5).

In addition, the 2017-2021 IAESB Strategy (IAESB, 2017) is based on continuous and innovative engagement with stakeholders; proactively identifying trends that impact the accounting profession to inform future standards development; providing impactful implementation support and undertaking a post-effective data review that will be used in the continuous improvement of IESs (Sugahara \& Wilson, 2013; Crawford et al., 2014; Cameran \& Campa, 2016).

Moreover, the 2017-2018 IAESB Work Plan displayed, for the next two years, the following priorities: supporting Standards development; maintaining and developing implementation support; planning a post-effective data review and improving strategic communication and stakeholder engagement.

IAESB's point of view on the relevance of accountancy education is illustrated in two documents, International Education Papers (IEP) 1 and 2. These IEPs respectively explore the relationship between IFAC's member bodies and education providers such as universities and what constitutes competence in professional accountants.

Specifically, the International Education Standard n. 2 (IES 2 - Initial Professional Development - Technical Competence) prescribes the learning outcomes for the technical competence that aspiring professional accountants are required to demonstrate by the end of their initial professional development (IPD); these learning outcomes are listed below:

a. Financial Accounting and reporting;

b. Management accounting;

c. Finance and financial management;

d. Taxation;

e. Audit and assurance;

f. Governance, risk management and internal control;

g. Business laws and regulations;

h. Information technology;

i. Business and organizational environment;

j. Economics;

k. Business strategy and management.

IFAC calls member bodies to regularly review and update professional accounting education programs that are designed to achieve the learning outcomes (par. 8, IES 2, IAESB 2014).

In Italy, the IFAC member is the National Council of Certified Accountants and Accounting Experts (Consiglio 
Nazionale dei Dottori Commercialisti e degli Esperti Contabili - CNDCEC) which is representative of professional accountants and responsible at a national level for the CPT.

Obviously, the CNDCEC can delegate universities for some courses but cannot have any influence on the university process for the proposals of the "educational offer" which is regulated by the national law and managed by the Ministry of Education and Research (MIUR).

\section{Research Methodology}

The study aims to test whether Italian university education programs are aligned with the International Education Standard n. 2 (IES2) containing the learning outcomes for technical competence, that aspiring professional accountants are required to demonstrate by the end of their initial professional development.

The basic idea is to verify if the learning outcomes that are contained in the IES n.2 are included as courses in the Italian university accounting programs for undergraduate or graduate degrees and to what extent the respondents have already acquired them during their course of study.

This primary research question has been expanded to consider professional accountants' beliefs on the present (which of these courses are really necessary for their workplace) and future (which of these courses will be necessary for their workplace within the next five years).

To this end, qualitative data was gathered through a questionnaire on professional accountants' views on their perception of quality in university programs of accounting education with reference to the technical competence as in the IES 2 and an area for suggestions.

Structuring this survey around the perceptions of the interviewees underlines their views and allows to understand the importance of current developments in the accounting professional sector in Italy. Questions at interviews have been pre-set with open-ended questions in order to have an appreciation of the general context as well as deal with matters of particular interest.

The advantages of such an approach are twofold: first, it gives the actors of the Italian accounting profession a voice and, second and consequently, it shifts the analysis from the self-referential perspective of an academic to one that takes as a starting point the experiences of practitioners.

The majority of the interviews were conducted in 2016 during the month of December and the latest in 2017 during the month of January. They were semi-structured interviews and some of them face-to-face.

The survey involved a small sample of key stakeholders (twenty-one interviewees).

The accountants selected attended in the last year or are attending in this academic year a university postgraduate course (Master for the Economic and Accounting professions at the University of Rome "Tor Vergata") to prepare themselves to pass the State examination to become a chartered accountant. They have studied at different universities, both males, and females, with ages ranging from around 25 to 40 years.

In a second step of the survey, the sample was extended with the interviews to four chartered accountants with significant experience of education programs for the accounting profession. Two of them were selected because they are also academics, employed as lecturers on the same postgraduate course, one is in charge of the organizing the training courses for postgraduates, while the another is responsible for the institutional relationships of the National Council of Certified Accountants and Accounting experts (CNDCEC). The purpose of these supplementary interviews was to understand their experience in the Accounting program as well as analyse the responses to the paper draft findings.

The questionnaire consists of three sections.

The first consists of three "multiple choice questions", which aim to verify if university education programs are aligned with the International Education Standard n. 2 (IES2), containing the learning outcomes for technical competence, those aspiring professional accountants are required to demonstrate by the end of their initial professional development (as mentioned above). In particular, this section examines the perceptions of graduating students on the skills and attributes they consider important to their career, as well as the emphasis placed on the development of these skills during their degree program. 
Table 1. Section one - University education programs vs learning outcomes according to IES2

Question no. 1 - What technical skills (listed below) did you acquire at university during your degree program?

Financial accounting and reporting

National Accounting Standards

International Accounting Standards

Management accounting

Finance and financial management

Taxation

Audit and assurance

Governance, risk management and internal control

Business laws and regulations

Information technology

Business and organizational environment

Economics

Business strategy and management

Question no. 2 - What technical skills (listed above) do you believe are necessary for professional accountants nowadays? (add more if required)

Financial accounting and reporting

National Accounting Standards

International Accounting Standards

Management accounting

Finance and financial management

Taxation

Audit and assurance

Governance, risk management and internal control

Business laws and regulations

Information technology

Business and organizational environment

Economics

Business strategy and management

Other technical skills:

Question no. 3 - What technical skills (listed above) do you believe will be necessary for professional accountants in the next 5 years? (add more if required)

Financial accounting and reporting

National Accounting Standards

International Accounting Standards

Management accounting

Finance and financial management

Taxation

Audit and assurance

Governance, risk management and internal control

Business laws and regulations

Information technology

Business and organizational environment

Economics

Business strategy and management

Other technical skills:

The second section contains two open questions about the general perception of the quality of accounting education and professional skill expectations. This section elicits respondents' views on the relationship between university education and the accounting profession in Italy. 
Table 2 Section two - Perception of the quality of accounting education vs professional skill expectations

Question no. 4: What is your perception of the quality of university education?

Question no. 5: Is it suitable for the accounting profession?

Finally, the third section asks for information related to the respondents' profile (as an academic and professional accountant, a non-academic professional accountant, or practicing accountant).

\section{Results and discussions}

Question no. 1: What technical skills did you acquire at university during your degree program?

Across the survey group, all the technical skills listed below are already considered during the university education program of "Economics" that prepares students for the accounting profession as well as any other job opportunities (managers, business economics advisors, etc.). However, the results underlie that no student has the same skills. This depends on the study plan chosen (where some courses are mandatory and others are optional).

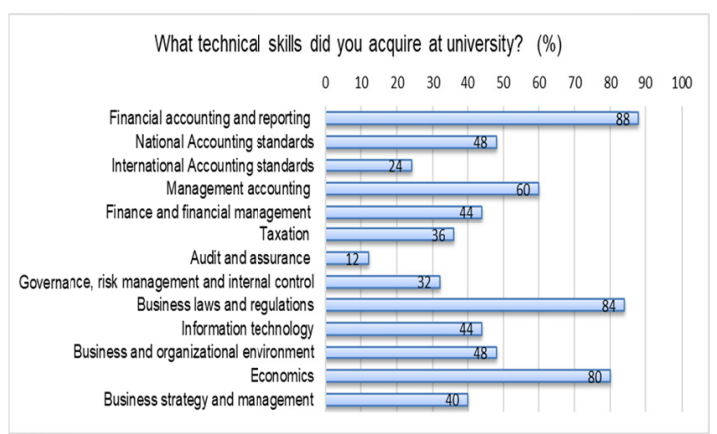

Figure 1. Technical skills acquired at university during the degree program

The table shows how there are three technical competencies that are considered the most important (in fact, they are often compulsory in university programs): "Financial accounting and reporting" (88\%), "Business laws and regulations" (84\%) and "Economics" (80\%). It is worth noting how in Italy "National Accounting Standards" and "International Accounting standards" could often be included in other courses (such as "Financial accounting and reporting").

Question no. 2: What technical skills do you believe are necessary for professional accoumtants nowadays?

The data reveal that $88 \%$ per cent of the participants confirm the importance of "Financial accounting and reporting" and "Business laws and regulations" (80\%) in their activity, but "Economics" (28\%) they underlie their need to study more "Taxation" $(80 \%)$ and "International Accounting standards" $(72 \%)$ than in the past.

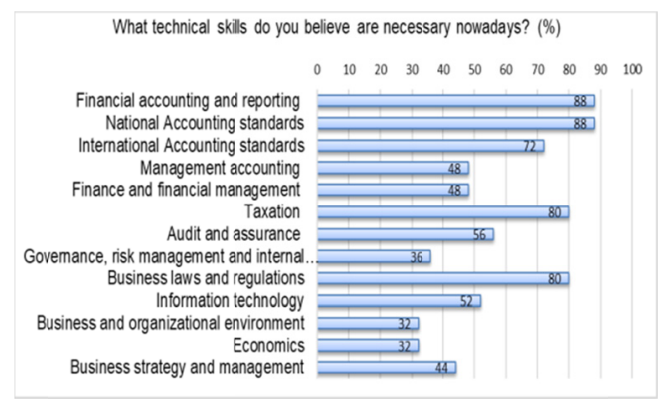

Figure 2. Technical skills for professional accountants

Question no. 3: What technical skills do you believe will be necessary for professional accountants in the next 5 years?

Looking at the future, the majority of the respondents recognized the greater relevance of "International accounting standards" (76\%) in the logical of a process of internationalization of micro and small enterprises. They consequently give less importance to courses such as (National) "Taxation" (72\%), "Financial accounting 
and reporting" (68\%) and "National Accounting Standards" (64\%). It is also possible to observe how instead of "Economics" (which dramatically decreases to $16 \%$ ), the course in "Business strategy and Management $(48 \%)$ is supposed to become more relevant than today ( $44 \%$ in table 2$)$.

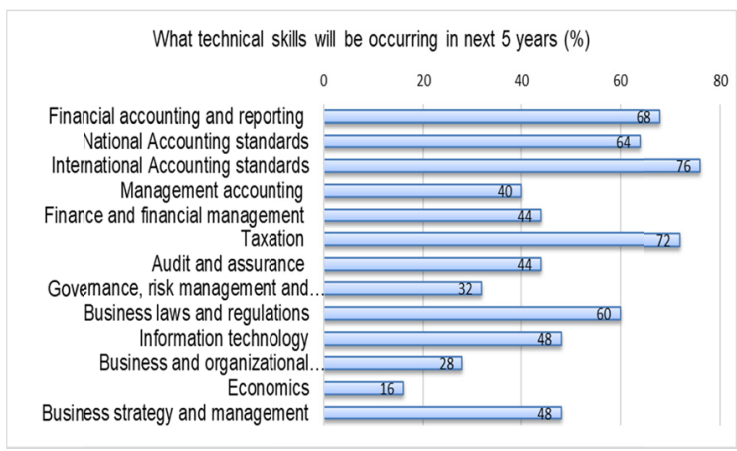

Figure 3 - Technical skills for professional accountants in the future

The respondents highlight their need to have practical cases to solve and suggest increasing the opportunity of stages. These suggestions confirm how the global economy is changing the mind and role of the 'traditional accountant' to one of 'advisor', as mentioned above.

Question no. 4: What is your perception of the quality of university education?

Question no. 5: Is it suitable for the accounting profession?

The answers to the last two questions can be ordered into three groups with reference to:

a. university education on a Bachelor's degree: of the 14 interviewees, only 1 responded that his perception of accounting education was appropriate for the accounting profession; all the others complained of different gaps in their skills;

b. university education on a Master's degree: of the 9 interviewees, only 3 responded that their accounting education was appropriate for the accounting profession; all the others complained of different gaps in their skills;

c. university education in an old degree program (4-year degree under the Italian Law n. 341/90 before the reform): of the 11 interviewees, only 2 of them were satisfied with their accounting background.

Although all the interviewees reported the quality of general skills achieved at university or obtained high-grade qualifications, the almost 'universal' consensus was that to be considered reliable as a professional accountant, it was critical to possess practical skills. One respondent explained that: "I believe that to carry out the accounting profession we need more than the skills acquired on the books... we need many hours of practice, analysing and solving cases of the actual profession".

Similarly, another interviewee states that: "The degree program was organized in such a way to better deal with issues related to the management of an enterprise rather than accounting".

Feedback from other interviewees demonstrated a willingness of students to work closely with certified accountants to improve their skills during their degree courses, as highlighted by the following comments: "We need practical knowledge (and not only theoretical) to become professional accountants. University education lacks training in connection with certified accountants, therefore we must attend other postgraduate courses such as the "Master for the Economic and Accounting professions".

During the course of the interviews, it became apparent that other subjects are important for the future of the accounting profession in a global economy; some interviewees stressed the relevance of tax disputes, bankruptcy law, international trade law and international tax law. Others underlined that university subjects are too theoretical and in addition, management-oriented to big firms, not to small entities (SMEs), since $99 \%$ of Italian organizations, where it is more likely to find job opportunities.

\section{Concluding Remarks}

A review of current literature highlighted how the gap between the competencies (knowledge, skills and personal attributes) which professional accountants expect and perceive is very important in order to understand why accounting education should change. Considering how accounting programs have been criticized for failing to 
train graduates (American Accounting Association, 1986; Andersen et al., 1989; Brown \& McCartney, 1995; American Institute of Certified Public Accountants, 1998; Institute of Management Accountants, 1994; 1996, 1999; Albrecht \& Sack, 2000), it is therefore interesting to study in greater detail the expectation-performance gap in accounting education (Binh Bui \& Brenda Porter, 2010).

Assuming as a background the studies relating to the expectation-performance gap of accounting education, this paper reports the results of the interviews with a sample of Italian practitioners (recent accounting graduates) that addresses the following research question: what are professional accountants' views on quality in accounting education?

This primary research question is expanded to ascertain their opinions on the competencies which accounting graduates should possess and the accounting program's success in developing these competencies.

The research findings provide broad support to the education's expectation-performance gap indicated in the current literature. Italian university programs and course outcomes are still incongruent with the development of behavioral and practical skills requested of professional accountants. Graduate perceptions of their learning at the university supported these findings. In fact, the current university courses and graduate perceptions are not aligned with desirable professional attributes, as specified by accounting associations, like IAESB (Veneziani, Teodori, \& Bendotti, 2016). Aligning university curricula with the practical skills required by aspiring or professional accountants is easier said than done. It reveals the potential university barriers to meeting external standards.

This problem is probably worldwide. According to Robinson (2010), it is essential to think to reform public education. The author underlines that "the current system of education was designed, conceived, and structured for a different age": the consequence is that universities, like other education institutions "trying to meet the future by doing what they did in the past".

An aspiring professional accountant needs to acquire not only new professional knowledge but also practical skills, professional values, ethics, and attitudes.

There is a growing demand from certified accountants of cooperation with the university world in order to improve programs of accounting education for university degrees, but also for defining research projects that could be more practical and useful in their professional activity.

The importance to find academics available to finalize their research and courses on the real needs of professional accountants has increased over recent years. Their acceptance of cooperation would not only increase the process of innovation in professional education learning but also suggest the evolution of the accounting education methodology.

The findings of this study provide valuable input on a theme that has not been widely discussed in Italy. In fact, only some authors (Mandrone, Pastore, \& Radicchia, 2015) are writing on the phenomenon of "educational mismatch", in other words, on the gap between skills possessed (level of education or training) and demand (in order to do their jobs).

Although the number of interviewees restricts the generalizability of the findings, these first results of the paper contribute to the ongoing debate on "universities' commitment to embedding professional graduate attributes into their accounting programs" (Yap, Ryan \& Yong, 2014).

This study also provides new tips at both a national and international level with reference to the International Education Standards (IESs) and specifically to the Future Strategy and Priorities stated in the 2017-2021 IAESB Strategy and in the 2017-2018 IAESB Work Plan.

The survey has, however, several limitations. First, it considers just the case of accounting programs for professionals in Italian universities. Secondly, the findings relating to empirical evidence could not be replicated in other territorial contexts/destination.

In our opinion, a constructive extension of this paper could focus on the interactions between the accountants' experiences (as aspiring or certified accountants) and the academics' views and on how to fill the gap between what is being taught and the real demand of competence (not only for professional activities but also for private and public employers). Such a study should also compare the length of time taken to start the professional activity (or gain an employment) and the type of the new skills requested from the global market.

\section{References}

American Accounting Association. (1986). Future accounting education: preparing for the expanding profession. Special Report. New York, NY: AAA. 
American Institute of Certified Public Accountants. (1998). CPA Vision Project: focus on the Horizon Executive summary and CPA Vision Project Focus Groups: Public Practice, Industry and Government CPAs; Also Addendum: Student Focus Group. New York, NY: AICPA.

American Institute of Certified Public Accountants. (2004). The Supply of Accounting Graduates and the Demand for Public Accounting Recruits-2004 for Academic Year 2002-2003. New York, NY, AICPA.

Armitage, J. L. (1991). Academics' and practitioners' views on the content and importance of the advanced financial accounting course. Journal of Accounting Education, 9(2), pp. 327-340.

Andersen, A., \& Co., Y., Coppers, A., Lybrand, D. H., Sells, E., Whinney, M. M. P., Co., ... Touche', R. (1989). Perspectives on Education for Success in the Accounting Profession (The White Paper). New York, NY: The Big Eight.

Albrecht, W. S., \& Sack, R. J. (2000). Accounting Education: Charting the Course through a Perilous Future Sarasota, FL: AAA.

Bayerlein, L. (2015). Curriculum innovation in undergraduate accounting degree programmes through 'virtual internships'. Education+Training, 57(6), pp. 673-684. https://doi.org/10.1108/ET-09-2014-0110

Bayerlein, L., \& Timpson, M. (2017). Do accredited undergraduate accounting programmes in Australia meet the needs and expectations of the accounting profession?. Education + Training, 59(3), 305-322. https://doi.org/10.1108/ET-04-2016-0074

Birrell, B. (2006). Implications of low English standards among overseas students at Australian universities, People and Place, 144, 53-64.

Bui, B., \& Porter, B. (2010). The Expectation-Performance Gap in Accounting Education: An Exploratory Study, Accounting Education: an international journal, 19(1-2), 23-50, https://doi.org/10.1080/09639280902875556

Brown, R. B., \& McCartney, S. (1995). Competence is not enough: meta-competence and accounting education, Accounting Education: an international journal, 4(1), 43-53. https://doi.org/10.1080/09639289500000006

Byrne, M., Flood, B., Hassall, T., Joyce, J., Arquero Montano, J. L., Gonzalez, J. M., \& Tourna-Germanou, E. (2012). Motivations, expectations and preparedness for higher education: a study of accounting students in Ireland, the UK, Spain and Greece, Accounting Forum, 362, 134-144. https://doi.org/10.1016/j.accfor.2011.12.001

Cameran, M., \& Campa, D. (2016). Comments by the European Accounting Association on the International Accounting Education Standards Board Consultation Paper 'Meeting Future Expectations of Professional Competence: A Consultation on the IAESB's Future Strategy and Priorities', Accounting in Europe, 13(2), 295-303. http://dx.doi.org/10.1080/17449480.2016.1201578

Carmona, S. (2013). Accounting curriculum reform? The devil is in the detail. Critical Perspectives on Accounting, 24(2), 113-119. http://dx.doi.org/10.1016/j.cpa.2012.03.004

Collini, S. (2012). What are universities for? London: Penguin Books

Costa, M., Torrecchia, P., \& Sangster, A. (2013). Accounting education for accounting educators evidence from Italy - the case of SISSIS/TFA 2002-2013. Procedia - Social and Behavioral Sciences, 106, 295-307. https://doi.org/10.1016/j.sbspro.2013.12.035

Cranmer, S. (2006). Enhancing graduate employability: best intentions and mixed outcomes. Studies in Higher Education, 312, 169-184. https://doi.org/10.1080/03075070600572041

Crawford, L., Helliar, C., Monk, E., \& Veneziani, M. (2014). International Accounting Education Standards Board: Organisational legitimacy within the field of professional accountancy education. Accounting Forum, 38(1), 67-89. https://doi.org/10.1016/j.accfor.2013.09.001

De la Harpe, B., \& David, C. (2011). Major influences on the teaching and assessment of graduate attributes. Higher Education Research \& Development, 314, 493-510. https://doi.org/10.1080/07294360.2011.629361

De Lange, P., Jackling, B., \& Suwardy T. (2015). Continuing Professional Development in the Accounting Profession: Practices and Perceptions from the Asia Pacific Region. Accounting Education, 24(1), 41-56. https://doi.org/10.1080/09639284.2014.1002800

Duncan, J., \& Schmutte, J. (2006). Change in accounting programs: the impact of influences and constraints. The Accounting Educators'Journal, 16, 52-81.

European Commission. (2015). Annual Report on European SMEs 2014/2015. Retrieved from 
http://ec.europa.eu/growth/smes/business-friendly-environment/performance-review/

Felton, S., Buhr, N., \& Northey, M. (1994). Factors influencing the business student's choice of a career in chartered accountancy. Issues in Accounting Education, 9(1), 131-141.

Fielding, R. (2005). War for talents hits audit salaries. Accountancy Age, 31, 1.

Fondazione Nazionale dei Commercialisti. (2014). Rapporto 2014 sull'Albo dei Dottori Commercialisti e degli esperti contabili (pp. 7-9). Retrieved from http://www.fondazionenazionalecommercialisti.it/node/675.

Francis, G., \& Minchington, C. (1999). Quantitative skills: is there an expectation gap between the education and practice of management accountants? Accounting Education: an international journal, 8(4), 301-319. https://doi.org/10.1080/096392899330810

Frecka, T. J., \& Nichols, W. D. (2004). Characteristics of Master's in Accounting degree programs. Issues in Accounting Education, 192, 165-188. https://doi.org/10.2308/iace.2004.19.2.165

Freeman, M., \& Hancock, P. (2011). A brave new world: Australian learning outcomes in accounting education. Accounting Education, 203, 265-273. https://doi.org/10.1080/09639284.2011.580915

Freeman, M., Simpson, L., \& Taylor, T. (2008). Assurance of learning: An Australian experience. Paper presented at the The Association to Advance Collegiate School of Business AACSB International Conference, Hawaii.

Gallhofer, S., Haslam, J., \& Kamla R. (2009). Educating and Training Accountants in Syria in a Transition Context: Perceptions of Accounting Academics and Professional Accountants. Accounting Education, 184(5), 345-368. https://doi.org/10.1080/09639280903157988

Haigh, N. (1994). Promoting Intellectual Independence: A Legislative Catalyst. Hamilton: University of Waikato.

Hancock, P., Howieson, B., Kavanagh, M., Kent, J., Tempone, I., \& Segal, N. (2009). Accounting for the Future: More than Numbers. Report to the Australian Learning and Teaching Council. Retrieved from http://https://eprints.usq.edu.au/6333/4/Hancock_Howieson_Kavanagh_etal_v2_2009_PV.pdf

Hardré, P. L., \& Kollmann, S. L. (2012). Motivational Implications of Faculty Performance Standards. Educational Management Administration \& Leadership, 40(6), 724-751. https://doi.org/10.1177/1741143212456913

Marsh, H. W., \& Hattie, J. (2002). The Relation Between Research Productivity and Teaching Effectiveness: Complementary, Antagonistic, or Independent Constructs? The Journal of Higher Education, 73(5), 603-641. https://doi.org/10.1353/jhe.2002.0047

Hill, W. Y., \& Milner, M. M. (2007). The Placing of Skills in Accounting Degree Programmes in Higher Education: Some Contrasting Approaches in the UK. BMAF Magazine, 2, 3-4.

Institute of Management Accountants. (1994). What Corporate America Wants in Entry-Level Accountants. Executive Summary (with the Financial Executives Institute). Montvale, New Jork: IMA.

Institute of Management Accountants. (1996). The Practice Analysis of Management Accounting: Results of Research. Montvale, New Jork: IMA.

Institute of Management Accountants. (1999). Counting More, Counting Less: Transformations in the Management Accounting Profession. Montvale, New Jork: IMA.

International Accounting Education Standards Board. (2014). Handbook of International Education Pronouncements. New York: IFAC.

International Accounting Education Standards Board (2017). Basis of conclusions. 2017-2021 IAESB Strategy and 2017-2018 Work Plan. New York: IAESB.

International Accounting Education Standards Board. (2015). Meeting future expectations of professional competence: A consultation on the IAESB's future strategy and priorities. Consultation paper. Retrieved from https://www.bdo.global/getmedia/0282b61a-a21c-4ce2-bd0c-fd47f4006146/IAESB-Consultation-Paper-2017-20 21-IAESB-Strategy-and-Priorities.pdf.aspx

International Federation of Accountants (IFAC). (2002). International Education Standard on Professional Skills and General Education (New York: IFAC).

International Federation of Accountants. (2015a). An overview of the International Accounting Education Standards 
Board. Retrieved from https://www.ifac.org/publications-resources/overview-international-education -standards

International Federation of Accountants. (2015b). Charting the future global profession. Retrieved from https://www.ifac.org/system/files/publications/files/IFAC-Strategy-for-2016-2018.pdf

International Accounting Education Standards Board. (2002). International Education Paper 1, Recognition of precertification education providers by IFAC member bodies. New York: IFAC.

International Accounting Education Standards Board. (2003). International Education Paper 2, Towards Competent Professional Accountants. New York: IFAC.

International Accounting Education Standards Board. (2015). International Education Standard 2, Initial Professional Development-Technical Competence (Revised). New York: IFAC.

Istituto di Ricerca dei Dottori Commercialisti e degli Esperti Contabili. (2012). L'evoluzione della professione di Commercialista (p. 71). Retrieved from: http://www.fondazionenazionalecommercialisti.it/node/557.

Jackling, B., \& De Lange, P. (2009). Do accounting graduates' skills meet the expectations of employers? A matter of convergence or divergence. Accounting Education, 184(5), 369-385. https://doi.org/10.1080/09639280902719341

Jackson, M., Watty, K., Yu, L., \& Lowe, L. (2006). Assessing Students Unfamiliar with Assessment Practices in Australian Universities. Sydney: Carrick Institute of Learning and Teaching in Higher Education.

Jackson, D. (2009). Profiling industry-relevant management graduate competencies: The need for a fresh approach. The International Journal of Management Education, 8(1), 85-98. https://doi.org/10.3794/ijme.81.281

Jackson, D. (2016). Modelling graduate skill transfer from university to the workplace. Journal of Education and Work, 29(2), 199-231. https://doi.org/10.1080/13639080.2014.907486

Kavanagh, M. H. \& Drennan, L. (2008). What skills and attributes does an accounting graduate need? Evidence from student perceptions and employer expectations. Accounting \& Finance, 482, 279-300. https://doi/pdf/10.1111/j.1467-629X.2007.00245.x

Kerr, S. (1975). On the folly of rewarding A, while hoping for B. The Academy of Management Journal, 18(4), 769-783. https://doi: 10.2307/255378

Kochanek, R., \& Norgaard, C. (1985). Student perceptions of alternative accounting careers - Part II. The CPA Journal, 55(6), 26-32.

Lander, M. W., Koene, B. A. S., \& Linssen, S. N. (2013). Committed to professionalism: Organizational responses of mid-tier accounting firms to conflicting institutional logics. Accounting, Organizations and Society, 382, 130-148. https://doi: http://dx.doi.org/10.1016/j.aos.2012.11.001

Lindsay, D. H., \& Campbell, A. (1995). Accounting research as a determinant of teaching outcomes. Accounting Perspectives, 1(2), 39-56.

Lubbe, I. (2015). Educating professionals-perceptions of the research-teaching nexus in accounting a case study. Studies in Higher Education, 40(6), 1085-1106. https://doi.org/10.1080/03075079.2014.881351

Manakyan, W., \& Tanner, J. R. (1994). Research productivity and teaching effectiveness: accounting faculty perspective. The Accounting Educators' Journal, 6, 1-21.

Mandrone, E., Pastore, F., \& Radicchia, D. (2015). Educational mismatch: new empirical evidence from the ISFOL PLUS data. Retrieved from: http://www.aiel.it/cms/cms-files/submission/all20160620104811.pdf

Marriott, P., \& Marriot, N. (2003). Are we turning them on? A longitudinal study of undergraduate accounting student's attitudes towards accounting as a profession. Accounting Education: An International Journal, 12(2), 113-133. https://doi.org/10.1080/0963928032000091738

Mathews, M. R., Jackson, M., \& Brown, P. (1990). Accounting for higher education: Report of the review of the accounting discipline in higher education. Canberra: Australian Government Publishing Service.

Wolk, C., Schmidt, T., \& Sweeney, J. (1997). Accounting educators' problem-solving style and their pedagogical perceptions and preferences. Journal of Accounting Education, 15(4), 469-484. https://doi.org/10.1016/S0748-5751(97)00022-5

McGee, R. W. (2005). International accounting education and certification in the former Soviet Union. International Journal of Accounting, Auditing and Performance Evaluation, 21(2), 19-36. 
https://dx.doi.org/10.2139/ssrn.601821

McGee, R. W., \& Preobragenskaya, G. (2005). Accounting education in Ukraine. Social Science Research Network.

Millard, P. (2003). Promoting the profession. Chartered Accountant Journal of New Zealand, 82(1), 13.

Moya, S., Prior, D., \& Rodríguez-Pérez, G. (2015). Performance-based Incentives and the Behavior of Accounting Academics: Responding to Changes. Accounting Education, 24(3), 208-232. https://doi.org/10.1080/09639284.2014.947092

Murdoch, B., \& Guy, P. W. (2002). Active learning in small and large classes. Accounting Education: an international journal, 11(3), 271-282. https://doi.org/10.1080/0963928021000031448

Novin, A. M., Fetyko, D. F., \& Tucker, J. M. (1997) Perceptions of accounting educators and public accounting practitioners on the composition of 150-hour accounting programs: a comparison. Issues in Accounting Education, 2(2), 331-352.

Osmani, M., Hindi, N., Al-Esmail, R., \& Weerakkody, V. (2017). Examining graduate skills in accounting and finance: The perception of Middle Eastern students. Industry and Higher Education, 31(5), 318-327. https://doi.org/10.1177/0950422217721759

Parry, N., \& Jackling, B. (2015). How do Professional Financial Services Firms Understand their Skill Needs and Organise their Recruitment Practices? Accounting Education, 24(6), 514-538. https://doi.org/10.1080/09639284.2015.1109528

Parker, L. D. (2007). Professionalisation and UK accounting education: academic and professional complicity A commentary on 'Professionalising claims and the state of UK professional accounting education: some evidence'. Accounting Education, 16(1), 43-46. https://doi.org/10.1080/09639280601151044

Porter, B. A., \& Carr, S. A. (1999). From strategic plan to practical realities: developing and implementing a zero-based accounting curriculum. Issues in Accounting Education, 14(4), 565-588. https://doi.org/10.2308/iace.1999.14.4.565

Robinson, K. (2010). Changing Education Paradigms, RSA Animate, RSA Animate, The Royal Society of Arts, London. Retrieved from: https://www.ted.com/talks/ken_robinson_changing_education_paradigms.

Saemann, G. P., \& Crooker, K. J. (1999) Student perceptions of the profession and its effect on decisions to major in accounting. Journal of Accounting Education, 17(1), 1-22. https://doi.org/10.1016/S0748-5751(99)00007-X

Schultz, J. J., Meade, J. A., \& Khurana, I. (1989). The changing roles of teaching, research, and service in the promotion and tenure decisions for accounting faculty. Issues in Accounting Education, 4(1), 109-119.

Shivaswamy, M. K., \& Hanks, G. F. (1985a). Accounting education: how students view a career in management accounting. Management Accounting, 68(5), 32-34.

Shivaswamy, M. K., \& Hanks, G. F. (1985b). Attitudes towards governmental accounting: are students turned off? The Government Accountants Journal, 34(3), 58-61.

Sikka, P., Haslam, C., Kyriacou, O., \& Agrizzi, D. (2007). Professionalizing Claims and the State of UK Professional Accounting Education: Some Evidence. Accounting Education: an international journal, 16(1), 3-21. https://doi.org/10.1080/09639280601150921

Sugahara S. \& Wilson R. (2013). Discourse Surrounding the International Education Standards for Professional Accountants IES: A Content Analysis Approach. Journal: Accounting Education, 22(3), pp. 213-232. https://doi.org/10.1080/09639284.2013.785860

Stephenson, S. S. (2017). Accounting Community of Practice pedagogy: a course management invention for developing personal competencies in accounting education. Accounting Education, 26(1), 3-27. https://doi.org/10.1080/09639284.2016.1247008

Stice, J. D., \& Stocks, K. D. (2000). Effective teaching techniques. In Bill N. Schwartz, J. Edward Ketz (Eds.), Advances in Accounting Education Teaching and Curriculum Innovations (Advances in Accounting Education, Volume 2 pp.179 - 191). Emerald Group Publishing Limited.

Street, D. L., Baril, C. P., \& Benke, R. L. Jr. (1993). Research, teaching, and service in promotion and tenure decisions of accounting faculty. Journal of Accounting Education, 11(1), 43-60. https://doi.org/10.1016/0748-5751(93)90017-D

Swain, M. R., \& Stout, D. E. (2000). Survey evidence of teacher development based on AECC recommendations. 
Journal of Accounting Education, 18(2), 99-113. https://doi.org/10.1016/S0748-5751(00)00013-0

Tang, T. L. P., \& Chamberlain, M. (1997). Attitudes toward research and teaching: differences between administrators and faculty members. Journal of Higher Education, 68(2), 212-227. https://doi.org/10.1080/00221546.1997.11780882

Theuri, P. M., \& Gunn, R. (1998). Accounting information systems course structure and employer systems skills expectations. Journal of Accounting Education, 16(1), 101-121. https://doi.org/10.1016/S0748-5751(98)00005-0

Veneziani, M., Teodori, C., \& Bendotti, G. (2016). The role of the University in the Education of Professional accountants: degree of the IES 2 application, Journal of Modern Accounting and Auditing, 12(3), 127-146 https://doi.org/10.17265/1548-6583/2016.03.001

Willcoxson, L., Wynder, M., \& Laing, G. K. (2010). A whole-of-program approach to the development of generic and professional skills in a university accounting program. Accounting Education, 191(2), 65-91. https://doi.org/10.1080/09639280902886082

Wilson, R. M. S. (2011). Alignment in accounting education and training. Accounting Education, 201, 3-16. https://doi.org/10.1080/09639284.2011.555940

Yap, C., Ryan, S., \& Yong, J. (2014). Challenges Facing Professional Accounting Education in a Commercialised Education Sector. Accounting Education, 23(6), 562-581. https://doi.org/10.1080/09639284.2014.974196

\section{Notes}

Note 1. Legislative Decree 28 June 2005 n.139, that became effective from 1st January, 2008.

Note 2. A Professional Accountant must be registered at the territorial Order of Certified Accountants and Accounting Experts. In January 1, 2014, they were 115,067 divided into 143 territorial Orders. The greater Order is in Rome with 10,141 enrolled members (IRDEC, 2012; Fondazione Nazionale dei Commercialisti; 2014).

\section{Copyrights}

Copyright for this article is retained by the author(s), with first publication rights granted to the journal.

This is an open-access article distributed under the terms and conditions of the Creative Commons Attribution license (http://creativecommons.org/licenses/by/4.0/). 